Editorial

\title{
Muslim Intellectualism in the Wake of the Arab Uprisings
}

With the uprisings in the Middle East and North Africa come scores of intellectual initiatives and academic investigations geared toward understanding the forces and motives propelling these unprecedented developments. Conferences are being convened and special issues of journals are being dedicated to addressing some aspects of the current phenomena - not to talk of droves of "experts" (academic tourists?) pouring into the Muslim world for research. In short, the so-called "Arab Spring" - also known by the people from the region as revolution (thawra), uprising (intifäda), renaissance (nahda) and awakening $(\operatorname{s} a \hat{h} w a)^{1}-$ has been an intellectual treasure trove for academics in the areas of Middle Eastern Studies, Islamic Studies, and Comparative Politics.

Butare the attempts to explain these phenomena enough toguide the present and future Muslim generations to proper trajectories toward sociopolitical and intellectual success? This editorial is intended to argue that, despite the potential positive outcomes from recent initiatives, now is the opportune time for Muslims to seize in order to design future trajectories for their upcoming generations. The sociopolitical imperatives (civility, freedom, empowerment, pluralism, and happiness, to name a few), to which they aspire to respond, must be guided by, or anchored in, grand intellectual endeavors.

\section{The Status Quo}

Whether or not we agree, we are now in a brand-new era in the history of the world (particularly, the Muslim world) in which hitherto accepted theories on many issues - especially, from the Western perspectives, (peace, unrests, conflicts, civil society, social justice, etc.) - are rendered quite unconvincing. It is a time when once viable models for explaining events - particularly, regarding support for democracy, strategies 
for negotiations, conflict resolution, political alliance, etc., are hopelessly inconsistent. It is, certainly, a time when all prudent peoples must rethink their future. This is why Muslims around the world need their own serious and grand intellectual projects to guide them into the future.

However, the Arab uprisings are still ongoing with relative successes and monumental challenges yet to be fully digested or appreciated. They have inspired conferences around the world. After a successful conference in 2011 in Amman, Jordan, another one in Egypt, slated for June 10-12, 2012 and dubbed "Takaful 2012" (takāful: solidarity/ mutual responsibility), is set to provide "an interdisciplinary opportunity to present research in the areas of citizen engagement and philanthropic practice in the Arab region." 2 The significance of Jordan and Egypt as the host nations must not be lost. The topic of a two-day international conference (March 17 and 18, 2012) in Melbourne, Australia, is even more direct: "The Middle East in Revolt: the First Anniversary." The questions the organizers hope to be addressed represent the popular expectations of many other conferences:

1. What have been the motivating factors for the Arab revolt?

2. How relevant is Political Islam to this popular uprising?

3. How does the popular uprising for political accountability relate to sectarian divisions?

4. How has Obama's Mid-East policy impacted on the popular push for democracy?

5. What role has the new media played in the spread of the popular uprising?

6. Does the 'Arab street' speak with one voice?

7. Where is the Arab revolution going? ${ }^{3}$

In addition, professional and academic associations dedicate sections in their annual conferences to presentations and panels related to some aspects of the uprisings. On September 23, 2011, the Association of Muslim Social Sciences (AMSS, the co-publisher of this journal) held its fortieth annual conference on "Looking Beyond 9/11: Islam in the West and Democratic Trends in the Middle East and North Africa." Furthermore, several academic journals have dedicated special issues to addressing all dimensions of the "Arab Awakening." This present journal (AJISS) has already issued a "call for papers" for its 2012 special issue on "Muslims and Political Change." Truly ambitious are our expectations:

- Theoretical papers examining the successes and failures of the contemporary struggles to end authoritarian rule 
- Case studies, qualitative interviews, oral histories of key people or organizations, reports of movement participants

- The role of civil society, journalists, women's groups, and the youth in the anti-regime struggles

- Critical studies of the work of scholars who have aimed for political change in their societies

- The role of the ulama in promoting or resisting anti-regime forces

- Critical studies of the regimes, their structures of power, and their ability to either resist or not resist popular uprisings

- Muslim responses to some of the specific issues that have come to the fore - democracy, pluralism, and tolerance; women's rights; economic reform; and the recalibration of foreign policy

- Do Muslims in Western democracies have something distinctive to contribute to these efforts of regime change?

- Can the transition to democracy in Latin America offer lessons for Muslim efforts at changing to democracy elsewhere?

- Historical studies of underlying structural forces in contemporary political change, or previous efforts at democratization

- The role of Islam, secular nationalism, or modernization in contemporary political change. ${ }^{4}$

These intellectual ventures will surely bare desirable fruits, and they are more than likely to continue for the foreseeable future. My call for grand, Muslim-initiated, intellectual, endeavors does not, and cannot, deny the positive results from these already ambitious undertakings. In fact, my suggestion for AJISS to commission the 2012 special issue was born out of this conviction that studies are needed. But I am going further in this editorial to suggest that Muslims need more than these conferences and academic articles, despite their positive results and worthwhile merits. Grand and effective intellectual projects in the Muslim world in the decades past, could have anticipated, and perhaps guided, these current uprisings. Alternatively and preferably, they could have led to better governance and civility that may have rendered these uprisings unnecessary. 


\section{Toward a New Trajectory}

At this opportune time of new recalibrations, Muslim must dream big and set deliberate monumental agendas in motion that will guide both their ambitions and activities into the future. In other words, Muslims must create and establish grand intellectual projects beyond what they currently have. This is not to deny that several intellectual projects do exist, nor do I deny that their institutions are effective. Years before these uprisings, forward-looking Muslim intellectuals have already come to the realization that Muslim think tanks are needed to analyze the past and chart the course for the future, and so they established a few. The International Institute of Islamic Thought (IIIT, a co-publisher and sponsor of this journal), based in Herndon, Virginia, has been an ideal Muslim think tank for three decades (with branches in London, UK, and Amman, Jordan). Its objectives include:

- Serve as a think tank in the field of Islamic education, culture and knowledge.

- Formulate a comprehensive Islamic vision and methodology that will help Muslim scholars in their critical analysis of contemporary knowledge.

- Develop an appropriate methodology for understanding the Qur'an and the Sunnah of the Prophet.

- Develop an appropriate methodology for dealing with Islamic legacy and contemporary knowledge, in order to draw on the experiences of both past and present, to build a better future for the Ummah and humanity at large.

- Develop an appropriate methodology for understanding and dealing with the present situation of both the Ummah and the world in general, and the field of education in particular, in view of contemporary challenges and opportunities. ${ }^{5}$

This is quite an extensive list of objectives. Practically, the IIIT has been engaged in research and support for researchers, the publication of textbooks and scholarly works, as well as organizing conferences and workshops.

Another institution that was created for the intellectual enhancement of Muslims is the Institute of Ismaì'li Studies (IIS, London, UK). Although its name may impress upon readers its sectarian emphasis, the institute's programs are, nonetheless, general in dimension and focus more on an interdisciplinary approach to Islamic history and thought. ${ }^{6}$

Muslim intellectuals have also concluded that modern higher aca- 
demic institutions, which integrate all sorts of knowledge, are needed, and so they created some. To this end, the International Islamic Universities in Malaysia, Pakistan, and other places were created. ${ }^{7}$ This was to go beyond the purview of the think tanks, which are more conducive for the intellectual elite, to provide practical knowledge to as many average Muslims as possible. For the past three decades, these universities have educated thousands of students from tens of Muslim societies from every continent in all sorts of disciplines and professions. With the expectations to empower Muslims, these institutions are driven by the general philosophy that contemporary Muslim education must integrate Islamic revealed knowledge with social and human sciences. There is no doubt that these were a result of forward thinking by Muslims intellectuals, or that Muslims around the world have benefited immensely from these undertakings.

Yet, inasmuch as these endeavors are believed to bear much desired fruits, the recent uprisings have ushered in a new era in which more, robust, well-funded projects must be created in many Muslim countries and staffed with intelligent, visionary, independent researchers. In other words, more diverse and effective think tanks are needed in the Muslim world, where local universities will be more than ready to man their projects. But, given these expectations and ambitions, what is more critical than the space and environment in which to operate are the subjects and projects on which to work and the freedom and latitude with which to investigate.

\section{Suggested Topics and Approaches}

First of all, Muslim researchers must challenge the deeply rooted theories on, and approaches to, several topics. Some of the common approaches to discussions on Islam that need to be rethought include the binary approaches such as "Islam and democracy," "Islam and nationalism," "Muslims and the West," and "Islam and reform." There is nothing inherently wrong with this approach (I and many excellent scholars have used it). In fact, it remains a convenient way of informing the status of Islamic content vis a vis a particular concept. But it is still stuck in making comparisons and declaring Islam's position on those issues. Muslim researchers must go beyond these binaries to innovative ways of posing questions - questions that do not necessarily assume these dichotomous analyses even if they may be controversial. This change of approach requires them to pose questions differently on some broader and pressing issues, especially in the wake of these uprisings - issues such as: 
- global citizenship

- authority

- immigration

- urbanization

- cosmopolitanism

- international diplomacy

- $\quad$ social responsibility

- communication ethics

- sexuality

- $\quad$ spousal relations

- national identity

- civility

- aesthetics

The idea is to address these topics from both Islamic and secular perspectives, but in ways that would empower Muslims (theoretically and practically). Using the topic of "citizenship" here to illustrate, Muslim researchers may investigate beyond the common questions of what is citizenship, abstract responsibilities of citizens, citizenship policies of nations, and what does Islam say about citizenship, etc. Instead, their questions should delve deeper into the subjects, even if they involve controversies. For example:

- Beyond birth, should citizenship be based on some other factors or not? Why and why not?

- Practical implications for the "rights" and "responsibilities" of citizens?

- Can or should citizenship override religious differences or not? What would be the consequences? 
- How practical or impractical are the classical Muslims theories on citizenship? Which of them should be retained and which discarded?

- Can national citizenship be reconciled with "pan-Islamic" citizenship or not? Why and why not?

- Importantly, "how" can the aforementioned points be explained or applied to Muslim communities?

- Creating working papers on new policies and justifications regarding citizenship for Muslim nations.

These are only a few suggestions. But identifying one of these or any other topic as a subject of research and determining how deep a researcher can delve into each, must be his or her prerogative or must be based on the requirements of the project - but must always be contingent upon the intellectual and sociopolitical priorities of Muslim people. Upon being vetted, tested, selected, and invited to these intellectual projects, Muslim researchers must be fully supported and given unfettered freedoms to carry out their research, as financial support and unhindered liberty are crucial to the success of such projects. But in any case, the objective must be clear: carrying out a comprehensive research project and arriving at innovative and avant-garde results that can, in one practical way or another, transform Muslim communities in positive ways.

The outcomes of the research must be in the form of policy papers or blueprints that may be used for guiding Muslim societies. I know there are other initiatives and institutions like IIIT and IIS that I did not mention here, or of which I am not aware. But no matter where and who they are, I think my general suggestion still gains its significance when uninhibited latitude for researchers and their intense focus to transform Muslim societies are stressed. AJISS would be pleased to publish extensive proposals about establishing effective think tanks in specific Muslim societies around the world.

\section{This Issue}

We begin the last issue of AJISS 2011 with Norman K. Swazo's "Islamic Intellectualism: Rahman, Gadamer, and the Hermeneutics of the Qur'ān." He examines Rahman's “double-movement” theory of Qur'ānic interpretation as it relates to Gadamer's general approach to understanding history and textual interpretation. Swazo concludes that there is reason to see Rahman's theory as consistent with Gadamer's philosophical hermeneu- 
tics, albeit with some modification given Rahman's focus on psychologism and objectivity as part of his approach to Qur'ānic interpretation.

Abdul-Samad Abdullah follows with his "Role of Context and Objectives of the Surah in Shaping the Episodes of the Qur'ānic Narrative: The Narrative of Lot as an Example." He concludes that every episode of the narrative of Lot differs from the others in the series through its own identity, which is acquired from the surah in which it appears. Abdullah suggests that all the episodes in the narrative of Lot correspond with the context and the objectives of the surah and it would be inappropriate to move any episode in the narrative from one surah to another. In fact, he insists that such a shift in position would eventually lead to stylistic flaws related to the context and objectives of each surah.

The next article is "An Islamic Conceptual Framework of a Well-balanced Personality" by Nik Rosila Nik Yaakob. Through an extensive analysis of the Qur'ān and the Tradition, and with the aid of some diagrams, she presents a conceptual framework of a well-balanced personality in the light of an Islamic point of view. Nik Yaakob focuses on the three types of personality - that is, nafs al-muţmainnah, nafs al-ammärah, and nafs al-lawwämah.

We close with M. Mumtaz Ali's "Issues in Muslim Liberal and Islamic Revivalist Thought: An Analysis of the Views of Watt and Sikand." He makes a comparative analysis of some important issues in Muslim liberalist and contemporary Islamic revivalist thought as seen and discussed by William Montgomery Watt and Yoginder Sikand. Ali is critical of both scholars on the account that they consider Muslim liberalists thought as creative interpretations, which contribute constructively toward the development of Islamic thought. He insists at the same time that both maintain that Islamic revivalists demonstrate rigidity, idealism, and fundamentalism and cause the development of radical thought.

We are also pleased to present in the Forum section of this issue "Not Truth But Tolerance: A (Much Belated) Response to Atif Khalil." This is a rebuttal penned by Sherman A. Jackson to Atif Khalil's review of the former's book. ${ }^{8}$ Though "belated" as he admits, the rebuttal is timely for what it argues: "theological tolerance." Felt grossly misunderstood by Atif Khalil, Jackson is bent on clarifying the aim of his and al-Ghâzalî's work as primarily "not to establish who among the theological schools is 'right,' but to demonstrate the folly and unfairness of the practice of condemning a doctrine as heresy simply because it goes against one's own theology." Far from being apologetics, this is, by all accounts, an engaging piece; one that surely presents intellectual arguments for both how theological tolerance is necessary and how original texts are to be read. 
I am confident that, once again, we have assembled a group of excellent scholars for AJISS readers, who expect nothing less than stimulating and thought-provoking articles.

\section{Endnotes}

1. “A New Middle East” Editorial, The Nation, 293, no. 11 (2011): 3, www. thenation.com/sites/default/files/nation20110912_0.pdf.

2. www.aucegypt.edu/research/gerhart/rprogram/Pages/TakafulConference. aspx.

3. www.h-net.org/announce/show.cgi?ID $=188258 \&$ keyword $=$ conferences\&k eyword=Egypt.

4. Please refer to the last pages of this journal for more details about the "call for papers."

5. www.iiit.org/AboutIIIT/tabid/66/Default.aspx.

6. www.iis.ac.uk/view_article.asp?ContentID=104413.

7. www.iium.edu.my; www.iiu.edu.pk.

8. Atif Khalil, "Is an Intra-Islamic Theological Ecumenism Possible? A Response to Sherman Jackson," The American Journal of Islamic Social Sciences 22, no. 4 (2005): 84-95; Sherman A. Jackson, On the Boundaries of Theological Tolerance in Islam: Abū Hāmid al-Ghāzalī's Fayșal alTafriqa bayna al-Islam wa al-zandaqa. (Karachi, India: Oxford University Press, 2002).

Zakyi Ibrahim, Ph.D., Editor, California State University, Fullerton, zibrahim@fullerton.edu 